\title{
Economic Policy Uncertainty in the United States and Europe: A Cointegration Test
}

\author{
Vichet Sum \\ Correspondence: Vichet Sum, School of Business and Technology, University of Maryland - Eastern Shore, \\ Princess Anne, MD, 21853, USA. Tel: 1- 410-651-6531. E-mail: vsum@umes.edu \\ Received: August 22, $2012 \quad$ Accepted: December 20, $2012 \quad$ Online Published: January 11, 2013 \\ doi:10.5539/ijef.v5n2p98 URL: http://dx.doi.org/10.5539/ijef.v5n2p98
}

\begin{abstract}
Economic uncertainty is closely followed and analysed by businesses, policy makers and academic scholars because the world economies have now become very closely interconnected more than ever. This study is to examine a relationship between economic policy uncertainty between the United States and Europe. The results reveal a long-run equilibrium relationship (cointegration) in economic policy uncertainty between the United States and Europe. The findings provide evidence of the interconnectedness of economic conditions between the United State and Europe in line with the international transmission and spill-over literature.
\end{abstract}

Keywords: economic policy uncertainty, cointegration

JEL Classifications: E60

\section{Introduction}

The world economies have now become very closely interconnected more than ever; this phenomenon is, no doubt, a direct result of globalization. A shockwave related to any specific economic, social and political activities in one country can carry itself across the globe instantly due to technology advancement and rapid media coverage. According to the international transmission and spill-over literature (Awad \& Goodwin, 1998; Becker, Finnerty, \& Friedman, 1995; Forbes \& Chinn, 2004; Chinn \& Frankel, 2004; Ehrmann \& Fratzscher, 2009; Kim, 2001), a major structural economic or financial shock in one country can have a direct or indirect effect on the economies and financial markets of other countries and the world economies alike; this effect can be especially strong when this country is one of the leading economies in the world. Among many changes taking place in an advanced economy, changes related to economic policy are most likely followed and analysed by businesses, policy makers and academic scholars.

Why do changes in economic policies matter a lot? The answer to this question is that economic uncertainty perceived by consumers and investors can have a negative impact on economic recovery and growth. Consumers and investors hesitate to spend and invest as they sense higher uncertainty in the economy. According to Bernanke (1983), a high level of economic uncertainty incentivizes firms to delay potential investment projects and freeze hiring accordingly. The economy is likely to contract when firms postpone investment and employment decisions. Baker, Bloom, and Davis (2012) report that when uncertainty about future taxes, spending levels, regulations, health-care reform, and interest rates is high, consumers and businesses delay spending on investment and consumption. Rodrik (1991) shows that policy uncertainty is associated with firms' investment delay. Julio and Yook (2012) also empirically document a negative relationship between political uncertainty and investment activities. Moreover, economic uncertainty is associated with higher cost of finance (Gilchrist et al., 2010; Fernandez-Villaverde et al., 2012). Higher financing cost leads to lower investment and economic slowdown as a result.

The effect of economic uncertainty is also observed in the financial market. Financial market dislikes uncertainty. Bansal and Yaron (2004) document that increased economic uncertainty is associated with lower asset prices. Bansal, Khatchatrian and Yaron (2005) find that drop in asset valuations is linked to higher economic uncertainty. Ozoguz (2009) reports a negative relationship between equity prices and investors' perceived uncertainty. Dzielinski (2011) reports that in the week following a rise in economic uncertainty, aggregate stock returns fall. Paster and Veronesi (2011) propose that drop in stock prices should be significant when a higher uncertainty about the government policy is observed in the economy. 
Since economic uncertainty is likely most followed and analysed by businesses, policy makers and academic scholars and because the world economy has now become very closely interconnected more than ever, this study is to examine a relationship between economic policy uncertainty between the United States and Europe. This study is necessary because no prior study in the current literature examines this phenomenon before. This paper seeks to contribute to further the understanding of the interconnectedness in economic policy and uncertainty between the United States and Europe.

\section{Method and Data}

The index of monthly economic policy uncertainty in the United States and Europe spanning from 1993-2011 is constructed by Baker, Bloom, and Davis (2012). Equation (1) and (2) are employed to conduct a unit root test for economic policy uncertainty variables in Europe and the United States, respectively; this is the Augmented Dickey-Fuller test for unit root.

$$
\begin{aligned}
& \Delta E P U_{E U_{t}}=\lambda_{0}+\lambda_{1} E P U_{E U_{t-1}}+\lambda_{2} T+\sum_{i=1}^{p} \Psi_{i} \Delta E P U_{E U_{t-i}}+\varepsilon_{t} \\
& \Delta E P U_{U S_{t}}=\lambda_{0}+\lambda_{1} E P U_{U S_{t-1}}+\lambda_{2} T+\sum_{i=1}^{p} \Psi_{i} \Delta E P U_{U S_{t-i}}+\varepsilon_{t}
\end{aligned}
$$

Where:

$\triangle E P U_{U S_{t}}=$ Change in Economic policy uncertainty in the United States in time $t$

$\triangle E P U_{E U_{t}}=$ Change in Economic policy uncertainty in Europe in time $t$

$E P U_{E U_{t-1}}=$ Economic policy uncertainty in the Europe in time $t-1$

$E P U_{U S_{t-1}}=$ Economic policy uncertainty in the United States in $t-1$

$\triangle E P U_{U S_{t-i}}=$ Change in Economic policy uncertainty in the United States in time $t-i$

$\triangle E P U_{E U_{t-i}}=$ Change in Economic policy uncertainty in Europe in time $t-i$

$T=$ trend term

Equation (3) and (4) are carried out to test for a long-run equilibrium relationship (cointegration) in economic policy uncertainty between the United States and Europe. First equation (3) is run in order to obtain residuals; another Augmented Dickey-Fuller test for unit root in the residuals is tested using equation (4).

$$
\begin{gathered}
E P U_{E U_{t}}=\beta_{0}+\beta_{1} E P U_{U S_{t}}+u_{t} \\
\Delta u_{t}=\gamma_{0}+\gamma_{1} u_{t-1}+\gamma_{2} T+\sum_{i=1}^{p} \Theta_{i} \Delta u_{t-i}+\varepsilon_{t}
\end{gathered}
$$

Where:

$\Delta u_{t}=$ The change in the error term (residual) in time $t$ obtained from equation 3

$u_{t-1}=$ The error term (residual) in time $t-1$ obtained from equation 3

$\Delta u_{t-i}=$ The change in the error term (residual) in time $t-i$ obtained from equation 3

$T=$ trend term

\section{Results}

First, in order to determine the appropriate length of lags to be included in the model, Schwarz's Bayesian information criterion (SBIC), the Akaike's information criterion (AIC), and the Hannan and Quinn information criterion (HQIC) tests are conducted; the results suggest 5 lags. As shown in Table 1 and 2, the economic policy uncertainty index in the United States is non-stationary, and so is the economic policy uncertainty index of Europe. Therefore, a cointegration test is appropriate to test for a long-run equilibrium relationship between the two variables. As shown in Table 4, the ADF test for unit root in the residuals obtained from equation (3) using equation (4) shows that the residuals are stationary with $Z(t)=-3.171$ significant at a $5 \%$ level. As a result, there is a long-run equilibrium relationship (cointegration) in economic policy uncertainty between the United States and Europe. 
Table 1. ADF test of economic policy uncertainty in europe (equation 1)

\begin{tabular}{lcccc}
\hline \multicolumn{2}{l}{ Augmented Dickey-Fuller test for unit root } & \multicolumn{2}{c}{ Number of observations $=222$} \\
\cline { 3 - 5 } & & & Interpolated Dickey-Fuller \\
& Test Statistic & $1 \%$ Critical Value & $5 \%$ Critical Value & $10 \%$ Critical Value \\
$Z(t)$ & -2.254 & -3.469 & -2.882 & -2.572 \\
\hline
\end{tabular}

MacKinnon approximate $\mathrm{p}$-value for $\mathrm{Z}(\mathrm{t})=0.1872$

Table 2. ADF test of economic policy uncertainty in the united states (equation 2)

\begin{tabular}{lcccc}
\hline \multicolumn{2}{l}{ Augmented Dickey-Fuller test for unit root } & & Number of observations $=222$ \\
\cline { 3 - 5 } & & & Interpolated Dickey-Fuller & \\
& Test Statistic & $1 \%$ Critical Value & $5 \%$ Critical Value & $10 \%$ Critical Value \\
$Z(t)$ & -1.227 & -3.469 & -2.882 & -2.572 \\
\hline
\end{tabular}

MacKinnon approximate $\mathrm{p}$-value for $\mathrm{Z}(\mathrm{t})=0.6620$

Table 3. Regression results of equation 3

Economic policy uncertainty index of Europe in time tis regressed on economic policy uncertainty index of the United States in time $t$.

\begin{tabular}{lcccc}
\hline$E P U_{E U_{t}}$ & Coefficient & Std. Err. & $\boldsymbol{t}$ & Sig. \\
\hline Constant & 5.65 & 6.1447 & 0.83 & 0.408 \\
$E P U_{U S_{t}}$ & 0.9583 & 0.0549 & 17.43 & 0.000 \\
R-Square & 0.5734 & & & \\
Adj. R-Square & 0.5715 & & & 0.000 \\
F(1, 214) & 303.79 & & & \\
\hline
\end{tabular}

Number of Observation $=228$

Table 4. ADF test of residuals obtained from running equation (3) using equation (4)

\begin{tabular}{llccc}
\hline \multicolumn{2}{l}{ Augmented Dickey-Fuller test for unit root } & & Number of observations $=222$ \\
\hline & & & Interpolated Dickey-Fuller & \\
\cline { 3 - 5 } & Test Statistic & $1 \%$ Critical Value & $5 \%$ Critical Value & $10 \%$ Critical Value \\
$Z(t)$ & -3.171 & -3.469 & -2.882 & -2.572 \\
\hline
\end{tabular}

MacKinnon approximate $\mathrm{p}$-value for $\mathrm{Z}(\mathrm{t})=0.0218$

\section{Conclusion}

A major structural policy change in one country can have a direct or indirect effect on the economics of other countries and the world economy alike; this effect can be especially strong when this country is one of the leading economics in the world. Among many changes taking place in an advanced economy, changes related to economic policy are closely followed and analysed by businesses, policy makers and academic scholars. This study is to examine a relationship between economic policy uncertainty between the United States and Europe. The results reveal a long-run equilibrium relationship (cointegration) in economic policy uncertainty between the United States and Europe. The provide evidence of the interconnectedness of economic conditions between the United State and Europe in line with the international transmission and spill-over literature.

\section{References}

Awad, M. A., \& Barry, G. K. (1998). Dynamic linkages among real interest rates in international capital markets. $\begin{array}{lllll}\text { Journal of International Money and } & \text { Finance, }\end{array}$ http://dx.doi.org/10.1016/S0261-5606(98)00032-1

Baker, S. R, Bloom, N., \& Davis, S. (2012). Measuring economic policy uncertainty. Stanford mimeo.

Bansal, R., \& Yaron, A. (2002). Risk for the long run: A potential resolution of asset pricing puzzles. Journal of Finance, 59(1), 1481-1509. http://dx.doi.org/10.1111/j.1540-6261.2004.00670.x

Bansal, R., Khatchatrian, V., \& Yaron, A. (2005). Interpretable asset markets? European Economic Review, 49, 531-560. http://dx.doi.org/10.1016/j.euroecorev.2004.09.002 
Becker, K. G., Finnerty, J. E., \& Friedman, J. (1995). Economic news and equity market linkages between the U.S. and U.K. Journal of Banking and Finance, 19, 1191-1210. http://dx.doi.org/10.1016/0378-4266(94)00079-I

Bernanke, B. (1983). Irreversibility, uncertainty and cyclical investment. Quarterly Journal of Economics, 98 , 85-106. http://dx.doi.org/10.2307/1885568

Chinn, M. D., \& Frankel, J. A. (1994). Financial Barriers in the Pacific Basin: 1982-1992. Journal of Economic Integration, 9(1), 62-79.

Dzielinski, M. (2011). Measuring economic uncertainty and its impact on the stock market. Finance Research Letters, 9(3), 167-175. http://dx.doi.org/10.1016/j.frl.2011.10.003

Ehrmann, M., \& Fratzcher, M. (2009). Global financial transmission of monetary policy shocks. Oxford Bulletin of Economics and Statistics, 71(6), 739-759. http://dx.doi.org/10.1111/j.1468-0084.2009.00561.x

Fernandez-Villaverde, J, Guerron-Quintana, P., Kuester, K., \& Rubio-Ramirez, J. (2012). Fiscal volatility shocks and economic activity. University of Pennsylvania mimeo.

Forbes, K. J., \& Chinn, M. D. (2004). A decomposition of global linkages in financial markets over time. Review of Economics and Statistics, 86(3), 705-722.

Gilchrist, S., Jae, W., Sim, S. J., \& Zakrajsek, E. (2010). Uncertainty, financial friction and investment dynamics. Working paper, Boston University and Federal Research Board.

Julio, B., \& Yook, Y. (2012). Political uncertainty and corporate investment cycles. Journal of Finance, 67(1), 45-84. http://dx.doi.org/10.1111/j.1540-6261.2011.01707.x

Kim, S. (2001). International transmission of U.S. monetary policy shocks: Evidence from VAR's. Journal of Monetary Economics, 48, 339-372. http://dx.doi.org/10.1016/S0304-3932(01)00080-0

Ozoguz, A. (2008). Good times or bad times? Investors' uncertainty and stock returns. Review of Financial Studies, 22(11), 4377-4422. http://dx.doi.org/10.1093/rfs/hhn097

Pastor, L., \& Veronesi, P. (2012). Uncertainty about government policy and stock prices. Journal of Finance, 67(4), 1219-1264. http://dx.doi.org/10.1111/j.1540-6261.2012.01746.x

Rodrik, D. (1991). Policy uncertainty and private investment. Journal of Development Economics, 36, 229-242. http://dx.doi.org/10.1016/0304-3878(91)90034-S 